\title{
Introduction to Fruit Crops
}

\begin{abstract}
Mark Rieger
Introduction to Fruit Crops combina un formato muy amigable con una exhaustiva revisión de los hechos esenciales respecto del cultivo de especies frutales mundialmente importantes. Por lo tanto, es un libro muy útil como texto de referencia en cursos de introducción a la fruticultura y al mismo tiempo es una buena referencia para profesionales y agricultores. Este libro describe importantes cultivos frutales como banano, café, cocotero, frutilla, manzano, naranjo, nueces, olivo, palma aceitera africana y vid. Además, incluye información sobre nombres científicos, morfología vegetal, propagación, descripción botánica, polinización, clima, patrones, diseño de huertos, conducción y poda, y aspectos de sanidad vegetal.
\end{abstract}

Su autor es Decano del College of Agricultural and Life Sciences at the University of Florida., comenzó su carrera profesional como profesor de horticultura en la Universidad de Georgia, donde dictó varios cursos y dirigió proyectos sobre pomología.

\section{Introduction to Fruit Crops \\ Mark Rieger}

The Haworth Press Inc.

10 Alice Street

Binghamton NY 13904-7981

EUA

ISBN-13: 978-1-56022-259-0

462 pp, 30 capítulos y tres apéndices.

46 páginas a color.

Formato de $8,25 \times 10,75$ pulgadas.

Fecha de publicación: 2006

www.haworthpress.com

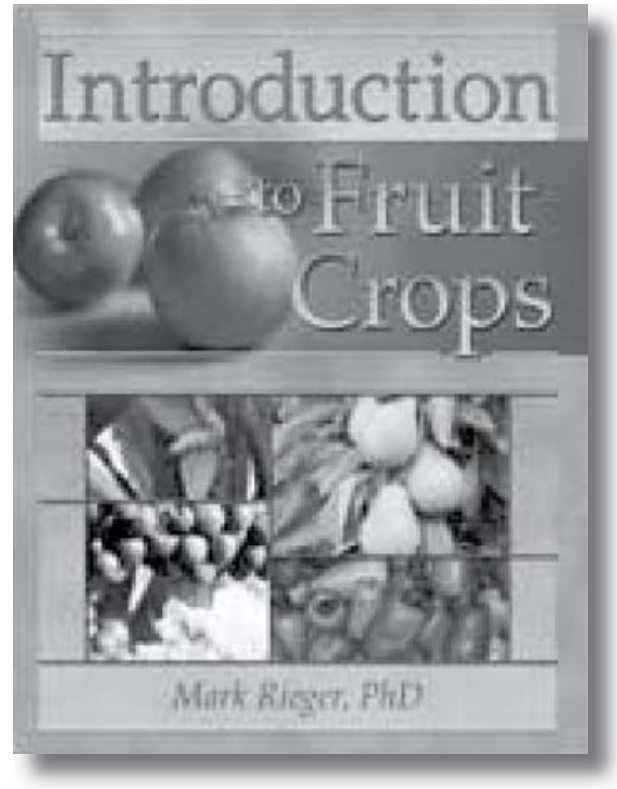

